\title{
Middle East Respiratory Syndrome
}

\author{
Novie H. Rampengan \\ Bagian Ilmu Kesehatan Anak Fakultas Kedokteran \\ Universitas Sam Ratulangi Manado \\ Email: novierampengan@yahoo.com
}

\begin{abstract}
Middle East Respiratory Syndrome (MERS) is a respiratory disease caused by Corona virus (MERS-CoV). This virus was first reported in 2012 in Saudi Arabia. World Health Organization (WHO) reported that until June 2015 there were 26 countries infected by MERS-CoV with a total of 1,334 laboratory confirmed cases of MERS-CoV infection and 471 deaths. According to WHO as many as $75 \%$ of MERS-CoV cases are secondary cases, obtained from other infected people. In mid 2015 it is reported that MERS-CoV attacked South Korea with 172 confirmed cases of MERS-CoV and 27 deaths. There are no approved antiviral agents for the treatment of MERS-CoV infection or vaccine available for the prevention of MERS-CoV. MERS cases are treated with supportive therapy such as hydration, antipyretics, analgesics, respiratory support, and antibiotics in case of secondary infection
\end{abstract}

Keywords: Middle East Respiratory Syndrome, Corona virus, treatment

\begin{abstract}
Abstrak: Middle East Respiratory Syndrome (MERS) merupakan penyakit saluran napas yang disebabkan oleh Corona virus (MERS-CoV). Virus ini pertama kali dilaporkan pada tahun 2012 di Arab Saudi. WHO melaporkan bahwa sampai Juni 2015 terdapat 26 negara terinfeksi MERS-CoV dengan total 1.334 kasus yang dikonfirmasi laboratorium terinfeksi MERS-CoV dan 471 kematian. Menurut WHO sebanyak 75\% dari kasus MERS-CoV merupakan kasus sekunder, yaitu diperoleh dari orang lain yang terinfeksi. Pada pertengahan tahun 2015 dilaporkan MERS-CoV menyerang Korea Selatan dengan 172 kasus yang dikonfirmasi laboratorium terinfeksi MERS-CoV dan 27 kematian. Belum ada antivirus yang disetujui untuk pengobatan infeksi MERS-CoV atau vaksin yang tersedia untuk pencegahan MERS-CoV. Penanganan MERS-CoV dengan terapi suportif berupa hidrasi, antipiretik, analgetik, bantuan pernapasan, dan antibiotik bila terjadi infeksi sekunder.
\end{abstract}

Kata kunci: Middle East Respiratory Syndrome, Corona virus, penanganan

Middle East Repiratory Syndrome (MERS) merupakan penyakit saluran napas yang disebabkan oleh Corona virus tipe baru (MERS-CoV). Virus ini pertama kali dilaporkan pada tahun 2012 di Arab Saudi dan sejauh ini terkait dengan negara-negara di Semenanjung Arab dan sekitarnya (Uni Emirat Arab, Qatar, Oman, Yordania, Kuwait, Yaman dan Lebanon). ${ }^{1}$ MERS biasanya dimulai dengan batuk, demam dan sesak napas. Tampilan klinis MERS berkisar dari asimtomatik sampai sindrom distres pernapasan akut dan kegagalan multi organ yang menyebabkan kematian, khususnya pada individu dengan komorbiditas sebelumnya. ${ }^{2}$ Kebanyakan individu dengan MERS yang terkonfirmasi laboratorium telah berkembang menjadi penyakit pernapasan akut dan di antara 536 kasus yang dilaporkan pada 12 Mei 2014, angka kematiannya mencapai 30\%. ${ }^{1}$ Jumlah kasus dan kematian yang dilaporkan di Arab Saudi baru-baru ini telah revisi karena adanya dugaan kasus yang tidak dilaporkan. Jumlah kasus terbaru di negara tersebut telah meningkat menjadi 688 dan jumlah kematian meningkat menjadi 282 kasus dari 190 kasus, dengan angka 
kematian lebih dari $40 \% .^{3} \quad$ WHO melaporkan bahwa sampai 31 Mei 2015 terdapat 1180 kasus yang telah terkonfirmasi laboratorium positif MERS dengan 483 pasien meninggal (mortalitas 40\%), terdiri dari kasus community acquired, hospital acquired dan transmisi human-to-human di masyarakat.,

Individu yang berisiko termasuk pengasuh dan orang yang mempunyai riwayat kontak dekat dengan orang yang dicurigai atau dikonfirmasi MERS-CoV. Transmisi terjadi melalui kontak dekat dengan orang yang terinfeksi, termasuk dari pasien ke petugas kesehatan. Pemeriksaan laboratorium khusus untuk MERS-CoV tidak tersedia secara rutin, namun polymerase chain reaction (PCR) untuk MERS-CoV tersedia di beberapa laboratorium pelaksana dan balai penelitian dan pengembangan kesehatan (BALITBANGKES) di Jakarta. Hingga saat ini belum ada vaksin yang tersedia untuk MERS dan belum ada pengobatan khusus yang telah direkomendasikan. Tatalaksana saat ini ialah terapi suportif, ${ }^{5}$ namun ada kelompok kesehatan yang telah merekomendasikan pertimbangan menggunakan interferon alfa $2 b$ dengan ribavirin dalam pengelolaan kasus MERS-CoV karena kombinasi obat ini terlihat khasiatnya pada kera dengan MERS. ${ }^{6}$

MERS-CoV saat ini telah menyebar di Korea Selatan. Kejadian ini merupakan fakta bahwa corona virus sering kali dapat bermutasi, di mana hal ini meningkatkan kekhawatiran bahwa MERS bisa menjadi pandemik. ${ }^{7}$ MERS terus menjadi ancaman kesehatan pada masyarakat tingkat rendah dan ancaman epidemik karena jutaan peziarah dari 184 negara bepergian ke Arab Saudi setiap tahun untuk haji dan umroh. ${ }^{3}$

\section{Etiologi}

Awalnya, virus ini dinamakan Human Coronavirus-EC, tapi kemudian oleh konsensus global diubah menjadi MERS$\mathrm{CoV}^{2,8}$ Virus ini merupakan spesies beta Coronavirus garis keturunan $\mathrm{C}$ yang baru saja ditemukan dan menginfeksi manusia (Gambar 1). ${ }^{8}$ Struktur genom MERS-CoV menggambar-kan dipeptil-peptidase 4 (DPP4, atau CD26) diidentiikasi sebagai reseptor host-sel untuk entry sel. ${ }^{2}$ MERSCoV berasal dari keluarga Corona virus. Corona virus pada manusia pertama kali diklasifikasikan pada pertengahan 1960-an. Alpha, beta, gamma dan delta merupakan sub kelompok Corona virus. Saat ini ada enam Corona virus yang dapat memengaruhi manusia yaitu: ${ }^{9}$

1. Corona virus Alpha: Corona virus 229E manusia dan Corona virus NL63 manusia (HCoV-NL63, New Haven coronavirus).

2. Corona virus Beta: Corona virus OC43 manusia, Corona virus HKU1 manusia, SARS-CoV, dan MERS-CoV

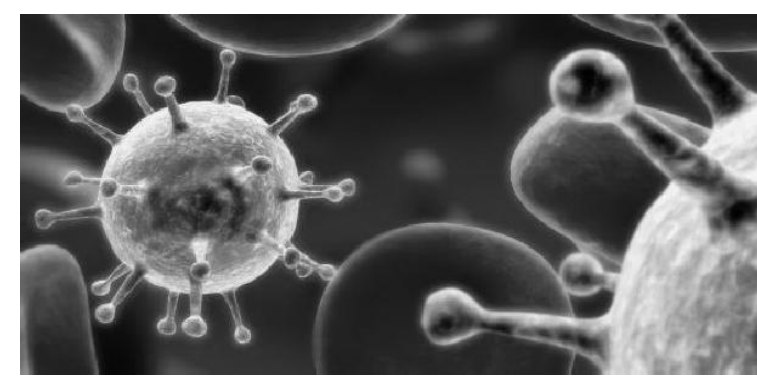

Gambar 1. Virus MERS dari golongan Coronavirus $^{17}$

MERS-CoV pertama kali dilaporkan di Arab Saudi. Asal virus ini masih belum diketahui. Studi awal menunjukkan bahwa MERS-CoV mungkin berhubungan dengan virus Zoonosis yang ditemukan di kelelawar, ${ }^{10}$ tetapi bukti yang terbaru menunjukkan bahwa virus ini mungkin lebih banyak ditemukan pada unta. ${ }^{11-16}$ Corona virus biasanya menginfeksi satu jenis spesies atau yang terkait erat. Hal ini berdasarkan penyelidikan 2 kasus manusia yang terinfeksi MERS-CoV bulan Oktober 2013 dan dilakukan pemeriksaan pada unta Dromedaris di sebuah peternakan di Qatar yang terkait dengan 2 kasus tersebut. MERS-CoV secara virologi dikonfirmasi melalui spesimen hidung unta tersebut. ${ }^{17}$ Kemungkinan penularan MERS dapat 
melalui kontak langsung dari percikan dahak dan tidak langsung melalui kontak dengan benda yang terkontaminasi virus. ${ }^{8}$

\section{Epidemiologi}

Sampai Juni 2015 terdapat 1.334 kasus MERS-CoV yang dikonfirmasi dengan laboratorium dan 471 kematian telah dilaporkan ke WHO. ${ }^{18}$ Terdapat 26 negara yang melaporkan kasus MERS, yaitu: Saudi Arabia, Iran, Yordania, Kuwait, Lebanon, Oman, Qatar, Uni Emirat Arab, Yaman (Timur Tengah); Austria, Perancis, Jerman, Yunani, Italia, Belanda, Turki, Inggris (Eropa); Aljazair, Tunisia, Mesir (Afrika); Cina, Malaysia, Republik Korea, Thailand, Filipina (Asia); dan Amerika Serikat. Sebagian besar dari kasus ini terjadi di Arab Saudi. ${ }^{19}$

Sebuah pernyataan dari WHO pada bulan April 2014 menunjukkan bahwa 75\% dari kasus MERS yang dilaporkan tampaknya merupakan kasus sekunder yang diperoleh dari orang lain yang terinfeksi. ${ }^{20}$ Pada tahun 2015 ini dan masih berlanjut, wabah MERS telah melanda Korea Selatan dan pada tingkat lebih rendah di China, terdapat 172 kasus yang dikonfirmasi dan 27 kematian terkait telah dilaporkan. $^{21}$

\section{Gambaran klinis}

Laporan bahwa rata-rata masa inkubasi MERS-CoV adalah 5,2 hari, $^{22}$ tetapi jangka waktu sampai 12 hari juga telah dilaporkan. ${ }^{8,23}$ Gejala awal biasanya berupa demam $\left(\geq 38^{\circ} \mathrm{C}\right)$, batuk, menggigil, rhinorrhea, kelelahan dan mialgia. Gejala gastrointestinal termasuk anoreksia, mual, diare dan sakit perut juga telah dilaporkan. Gejala pernapasan berupa sesak napas dan dispnea, dapat menjadi dominan kemudian hari. Pada kasus yang lebih berat, pasien yang mengalami kegagalan nafas akut mungkin memerlukan ventilasi mekanis dan extra corporeal membrane oxygenation (ECMO). Beberapa pasien dengan kondisi yang parah dapat berkembang menjadi gagal ginjal akut (GGA) yang membutuhkan hemodialisis, limfopenia, trombositopenia dan kegagalan multiorgan dengan koagulopati. Usia yang lebih tua (lebih dari 60 tahun), anak-anak, wanita hamil dan penderita penyakit kronis seperti diabetes, hipertensi, imunokompromise, penyakit ginjal stadium akhir, penyakit jantung kronis, dan kondisi paru telah dikaitkan dengan presentasi yang lebih berat dan berisiko tinggi dengan kematian. ${ }^{8,23}$

Merujuk pada definisi kasus WHO, klasifikasi kasus MERS-CoV sebagai berikut: ${ }^{8}$

1. a. Kasus dalam penyelidikan bila dijumpai keadaan demam $\geq 38^{\circ} \mathrm{C}$ atau riwayat demam, batuk, pneumonia berdasarkan gejala klinis atau radiologis dan salah satu kriteria ini:

1. Riwayat perjalanan ke negara terjangkit (Timur Tengah) dalam waktu 14 hari.

2. Adanya petugas kesehatan yang sakit dengan gejala sama setelah merawat pasien infeksi saluran pernapasan akut (ISPA) berat terutama pasien yang memerlukan perawatan intensif.

3. Adanya klaster pneumonia (gejala penyakit yang sama) dalam 14 hari tanpa memperhatikan tempat tinggal atau riwayat berpergian.

4. Adanya perburukan perjalanan klinis yang mendadak meskipun dengan pengobatan yang tepat tanpa memperhatikan tempat tinggal atau riwayat berpergian.

b. Kasus dalam penyelidikan bila seseorang dengan ISPA ringan sampai berat yang memiliki riwayat kontak erat dengan kasus konfirmasi atau probable infeksi MERS-CoV dalam waktu 14 hari sebelum sakit.

2. a. Kasus probable bila seseorang dengan pneumonia atau acute respiratory distress syndrome (ARDS) dengan bukti klinis, radiologis atau histopatologis dan tidak tersedia pemeriksaan untuk MERS$\mathrm{CoV}$ atau hasil laboratoriumnya negatif pada satu kali pemeriksaan 
spesimen yang tidak adekuat dan adanya hubungan epidemiologis langsung dengan kasus konfirmasi MERS-CoV.

b. Kasus probable bila seseorang dengan pneumonia atau ARDS dengan bukti klinis, radiologis atau histopatologis dan hasil peme-riksaan laboratorium inkonklusif (skrining positif tanpa konfirmasi biomolekular) dan adanya hubungan epidemiologis langsung dengan kasus konfirmasi MERS-CoV.

3. Kasus konfirmasi bila seseorang yang terinfeksi MERS-CoV dengan hasil pemeriksaan laboratorium positif.

Hubungan epidemiologis langsung ialah bila dalam waktu 14 hari sebelum timbul sakit: ${ }^{24}$

1. Melakukan kontak erat, yaitu seseorang yang kontak fisik atau berada dalam ruangan atau berkunjung (bercakapcakap dengan radius 1 meter) dengan kasus probable atau konfirmasi ketika kasus sedang sakit. Termasuk kontak erat antara lain petugas kesehatan yang memeriksa, merawat, mengantar dan membersihkan ruangan di tempat perawatan kasus; orang yang merawat atau menunggu di tempat perawatan kasus; orang yang tinggal serumah dengan kasus dan tamu yang berada dalam satu ruangan dengan kasus.

2. Bekerja bersama dalam jarak dekat atau didalam satu ruangan.

3. Berpergian bersama dengan segala jenis alat angkut/kendaraan.

\section{Pemeriksaan laboratorium}

WHO dan Centers for Disease Control (CDC) merekomendasikan pengambilan spesimen dari lokasi dan waktu yang berbeda pada kasus tersangka MERS. Spesimen yang berasal dari saluran nafas bawah seperti dahak, aspirat trakea dan bilasan bronkoalveolar mempunyai titer virus tertinggi. ${ }^{24,25}$ Spesimen saluran pernapasan atas (nasofaring dan orofaring) tetap diambil terutama bila spesimen saluran napas bawah tidak memungkinkan dan pasien tidak memiliki tanda-tanda atau gejala infeksi pada saluran pernapasan bawah. Sampel dari saluran napas harus diambil setiap 2-4 hari untuk memastikan bersihan virus sesudah dua pemeriksaan menunjuk-kan hasil negatif. ${ }^{3}$ Virus MERSCoV juga dapat ditemukan di dalam cairan tubuh lainnya seperti darah, urine dan feses, tetapi kegunaan sampel tersebut dalam mendiagnosis infeksi MERS-CoV belum pasti. Pemeriksaan diagnosis laboratorium kasus infeksi MERS-CoV dilakukan dengan metoda RT-PCR dan dikonfirmasi dengan teknik sekuensing. ${ }^{8}$

Pada beberapa kasus, didapatkan bahwa konfirmasi positif hanya dalam spesimen sputum setelah hasil negatif atau ragu terhadap pemeriksaan PCR MERS$\mathrm{CoV}$ pada spesimen nasofaring dan orofaring. Spesimen dikatakan tidak adekuat apabila hanya diambil spesimen dari swab nasofaring tanpa disertai spesimen saluran pernapasan bawah, atau penanganan spesimen yang tidak baik dan dinilai berkualitas rendah dari hasil pemeriksaan laboratoris, atau diambil sangat terlambat dalam rentang perjalanan penyakit. ${ }^{24}$ Untuk mempertimbangkan kasus MERS yang dikonfirmasi melalui laboratorium, salah satu dari kriteria berikut harus dipenuhi: 1) Hasil PCR positif setidaknya pada 2 target tertentu yang berbeda pada genom MERSCoV atau 2) Satu hasil PCR positif untuk target tertentu pada genom MERS-COV dan hasil PCR tambahan yang berbeda memberikan hasil positif MERS-COV. ${ }^{25}$ Hasil laboratorium inkonklusif bila didapatkan: ${ }^{24}$

- Hasil positif pada pemeriksaan skrining yang tidak diikuti dengan pemeriksaan konfirmasi molekuler.

- Hasil pemeriksaan serologis dinyatakan positif pada pemeriksaan laboratorium.

- Harus mendapat pemeriksaan virologis dan serologis tambahan untuk dapat menetapkan konfirmasi kasus MERS-CoV

- Bila memungkinkan, gunakan spesimen yang berasal dari saluran pernapasan 
bagian bawah: dahak, aspirate endotracheal, cairan bilas bronkoalveolar.

- Jika kasus tidak memiliki gejala atau tanda infeksi saluran napas bawah dan tidak tersedia spesimen dari saluran napas bawah maka harus diambil spesimen nasofaring dan orofaring.

Tes PCR digunakan untuk mendeteksi dan mendiagnosis penyakit menular serta dapat digunakan untuk mengonfirmasi kasus positif dari pasien MERS-CoV dengan menggunakan sampel dari saluran pernapasan. $^{26}$ Pemeriksaan darah yang dapat menentukan apakah seseorang sebelumnya telah terinfeksi dapat menggunakan antibodi terhadap MERS-COV. Pengujian serologis juga tersedia untuk mengevaluasi pasien yang terinfeksi MERS-CoV ataupun kontak. Spesimen serum harus dikumpulkan selama fase akut penyakit (minggu pertama sakit) dan diulang selama fase pemulihan (>3 minggu setelah sampel awal didapatkan). Tes serologis ini tersedia dari CDC dan memerlukan persetujuan, karena hanya untuk tujuan penelitian atau pengawasan. Tes ini menggunakan Indirect Fluorescent Antibody (IFA) dan deteksi antibodi IgM-IgG dengan berbasis teknologi micro array protein (MAP). ${ }^{27}$

Spesimen harus tiba di laboratorium segera setelah pengambilan. Penanganan spesimen dengan tepat saat pengiriman adalah hal yang teramat penting. Sangat disarankan agar pada saat pengiriman spesimen tersebut ditempatkan di dalam cool box dengan kondisi suhu $0-4^{\circ} \mathrm{C}$ atau bila diperkirakan lama pengiriman lebih dari 3 hari disarankan spesimen dikirim dengan es kering. Tabel 1 memuat daftar spesimen yang dapat diambil berikut persyaratan penyimpanan dan pengirimannya. $^{25}$

Tabel 1. Daftar spesimen yang dapat diambil berikut persyaratan penyimpanan dan pengiriman ${ }^{25}$

\begin{tabular}{|c|c|c|c|c|c|}
\hline Jenis spesimen & $\begin{array}{l}\text { Media } \\
\text { pengiriman }\end{array}$ & $\begin{array}{l}\text { Pengiriman ke } \\
\text { laboratorium }\end{array}$ & $\begin{array}{l}\text { Kategori } \\
\text { bahaya } \\
\text { pengiriman }\end{array}$ & Catatan & $\begin{array}{l}\text { Spesimen } \\
\text { yang harus } \\
\text { diambil }\end{array}$ \\
\hline $\begin{array}{l}\text { Dahak yang dihasil-kan } \\
\text { secara alami }\end{array}$ & Tidak ada & $\begin{array}{l}\text { Dengan es, bila } \\
>24 \quad \text { jam } \\
\text { dibekukan }\end{array}$ & $\begin{array}{l}\text { Zat biologis, } \\
\text { kategori B }\end{array}$ & $\begin{array}{l}\text { Materi dari } \\
\text { napas bawah }\end{array}$ & Wajib \\
\hline Bilasan bronkoalveolar & Tidak ada & $\begin{array}{l}\text { Dengan es, bila } \\
>24 \quad \text { jam } \\
\text { dibekukan }\end{array}$ & Idem & $\begin{array}{l}\text { Terjadi } \\
\text { dilusi virus }\end{array}$ & $\begin{array}{l}\text { Bila } \\
\text { mungkin }\end{array}$ \\
\hline Aspirat trakea & Tidak ada & $\begin{array}{l}\text { Dengan es, bila } \\
>24 \text { jam } \\
\text { dibekukan }\end{array}$ & Idem & & $\begin{array}{l}\text { Bila } \\
\text { mungkin }\end{array}$ \\
\hline Aspirat nasofaring & $\begin{array}{l}\text { Media transpor } \\
\text { virus }\end{array}$ & $\begin{array}{l}\text { Dengan es, bila } \\
>24 \quad \text { jam } \\
\text { dibekukan }\end{array}$ & Idem & $\begin{array}{l}\text { Virus } \\
\text { terdeteksi }\end{array}$ & $\begin{array}{l}\text { Bila } \\
\text { mungkin }\end{array}$ \\
\hline $\begin{array}{l}\text { Kombinasi usap } \\
\text { hidung/tenggorokan }\end{array}$ & $\begin{array}{l}\text { Media transpor } \\
\text { virus }\end{array}$ & Dengan es & Idem & & Wajib \\
\hline Swab nasofaring & $\begin{array}{l}\text { Media transpor } \\
\text { virus }\end{array}$ & Dengan es & Idem & & Wajib \\
\hline $\begin{array}{l}\text { Jaringan yang diambil } \\
\text { dari biopsi atau otopsi } \\
\text { (termasuk paru-paru) }\end{array}$ & $\begin{array}{lr}\text { Media } & \text { transpor } \\
\text { virus } & \text { atau } \\
\text { garam fisiologis }\end{array}$ & $\begin{array}{l}\text { Dengan es, bila } \\
>24 \text { jam } \\
\text { dibekukan }\end{array}$ & Idem & & $\begin{array}{l}\text { Bila } \\
\text { mungkin }\end{array}$ \\
\hline $\begin{array}{l}\text { Serum untuk serologi } \\
\text { atau deteksi virus }\end{array}$ & Tidak ada & $\begin{array}{l}\text { Dengan es atau } \\
\text { dalam keadaan } \\
\text { beku }\end{array}$ & Idem & $\begin{array}{l}\text { Sampel } \\
\text { berpasangan } \\
\text { (minggu } \\
1 \& 3)\end{array}$ & Wajib \\
\hline $\begin{array}{l}\text { Spesimen darah (whole } \\
\text { blood) }\end{array}$ & $\begin{array}{l}\text { EDTA } \\
\text { antikoagulan }\end{array}$ & Dengan es & Idem & $\begin{array}{l}\text { Deteksi } \\
\text { virus } \\
\text { Minggu I }\end{array}$ & $\begin{array}{l}\text { Bila } \\
\text { mungkin }\end{array}$ \\
\hline
\end{tabular}




\section{Tatalaksana}

Seiring dengan perkembangan pesat, pilihan terapi yang efektif merupakan sebuah prioritas yang tinggi karena belum ada antivirus yang disepakati untuk pengobatan infeksi corona virus maupun vaksin yang tersedia untuk pencegahan. Terapi infeksi MERS adalah bersifat suportif tergantung kondisi keadaan pasien, berupa pemberian hidrasi, antipiretik, analgesik, bantuan pernapasan, dan antibiotik jika diperlukan untuk mengatasi infeksi sekunder. ${ }^{28,29}$

Pada pasien dengan gangguan pernapasan berat harus hati-hati dalam pemberian cairan intravena, karena resusitasi cairan secara agresif dapat memperburuk oksigenasi, terutama dalam situasi terdapat keterbatasan ventilasi mekanik. Pada pasien pneumonia komunitas dan diduga terinfeksi MERS$\mathrm{CoV}$, dapat diberikan antibiotik secara empirik (berdasarkan epidemiologi dan pola kuman setempat) secepat mungkin sampai diagnosis ditegakkan. Terapi empirik kemudian disesuaikan berdasarkan hasil uji kepekaan. ${ }^{28}$

WHO tidak merekomendasikan pemberian steroid dosis tinggi karena dapat menyebabkan efek samping serius berupa infeksi oportunistik, nekrosis avascular, infeksi baru bakteri dan kemungkinan terjadi replikasi virus yang berkepanjangan. Oleh karena itu, kortikosteroid harus dihindari kecuali diindikasikan untuk alasan lain. ${ }^{8,28}$ Selain itu dilakukan pemantauan secara ketat pasien dengan gangguan pernapasan berat bila terdapat tanda-tanda perburukan klinis seperti gagal napas, hipoperfusi jaringan, syok dan memerlukan perawatan intensif. ${ }^{28}$ Berikan terapi oksigen pada pasien dengan tanda depresi napas berat, hipoksemia (SpO2 $<90 \%$ ) atau syok. Mulai terapi oksigen dengan $5 \mathrm{~L} /$ menit lalu titrasi sampai $\mathrm{SpO} 2$ $\geq 90 \%$ pada orang dewasa yang tiak hamil dan $\mathrm{SpO} 2 \geq 92 \%-95 \%$ pada pasien hamil. ${ }^{28}$ Pada sel yang dikultur, MERS-CoV dihambat oleh interferon tipe 1 (IFN- $\alpha$ dan khususnya IFN- $\beta$ ) dan IFN- $\alpha 2 b$ yang dikombinasikan dengan ribavirin dilaporkan dapat mengurangi kerusakan paru dan mengurangi titer paru saat diberikan pada rhesus makaka dalam 8 jam inokulasi virus. Kombinasi ini diuji pada pasien dengan penyakit berat, menunjukkan perbaikan pada 14 hari tapi tidak pada 28 hari, mungkin karena diberikan pada fase lanjut penyakit. Beberapa obat menghambat MERS-CoV pada kultur sel, yaitu siklosporin dan asam mikofenolat. Beberapa obat lain (klorokuin, klorpromazin, loperamide, dan lopinavir) menghambat replikasi virus secara in vitro (konsentrasi efektif, 3-8 $\mu \mathrm{mol} / \mathrm{L}$ ), walaupun efektivitas obat ini pada pasien tidak diketahui. Inhibitor fusi peptida yang spesifik pada MERS-CoV, yang berfungsi sama dengan obat HIV enfurfirtide akan menghilangkan replikasi virus pada sel yang dikultur, sehingga memberikan pendekatan baru pada penanganan MERS. Antibodi penetralisir human monoclonal dan convalescent sera dari pasien yang sembuh dapat berguna untuk perawatan bila didapat pada waktu yang tepat. Penelitian metaanalisis post-hoc tentang SARS dan influenza berat menunjukkan penurunan angka mortalitas yang signifikan sesudah penanganan dengan antibodi dibandingkan dengan placebo atau tanpa penanganan (pooled odds ratio 0,25 confident interval $95 \% 0,14-0,45){ }^{29}$

Pusat pengendalian infeksi dan Kementrian Kesehatan (Kemkes) setempat harus dilaporkan segera jika terdapat kasus infeksi MERS-CoV. Langkah-langkah pengendalian infeksi yang tepat, termasuk penularan kontak dan tindakan pencegahan melalui udara harus dilakukan sambil mengobati pasien yang diduga terinfeksi MERS-COV. Konsultasi dengan spesialis penyakit menular sangat dianjurkan, dan konsultasi dengan spesialis paru harus dipertimbangkan jika komplikasi pernapasan parah berkembang.

\section{Edukasi pasien}

Tindakan pencegahan harus ditingkatkan termasuk yang berencana bepergian 
ke negara-negara endemik MERS. Apabila terdapat tersangka yang mengunjungi negara endemik dan mengalami gejala berupa demam, batuk, sesak napas atau mialgia selama perjalanan mereka atau dalam waktu 14 hari setelah kembali, sangat dianjurkan untuk mencari bantuan medis. $^{26}$

\section{Vaksin MERS}

Belum ditemukan obat yang bekerja melawan MERS sampai saat ini. ${ }^{8}$ Dalam studi terbaru, para peneliti mengidentifikasi struktur molekul papain seperti protease (PLpro) sebagai sebuah enzim yang beperan penting. Enzim ini menghilangkan selinang di ubiquitin dan ISG15-protein yang berperan dalam mengaktifkan respon imun secara efektif. Dengan menggunakan Kristal ografisinar-X, para peneliti mampu melihat struktur 3D bagaimana enzim PLpro berinteraksi dengan protein ubiquitin dan menentukan asam amino mana yang menggabungkan keduanya. Selain itu, para peneliti menggunakan model komputer dan simulasi untuk melihat asam amino mana yang mengikat PLpro dan ISG15 bersamasama. Setelah asam amino diidentifikasi, para peneliti memutasikan asam amino tersebut sehingga enzim PLpro tidak mampu berkomunikasi dengan ubiquitin dan ISG15, sehingga virus SARS terdeteksi oleh sistem kekebalan tubuh. Tim kemudian menguji enzim PLpro untuk memastikan enzim tersebut masih mampu memicu proses replikasi virus. ${ }^{20,21}$

Ini adalah langkah pertama ke depan untuk menciptakan virus lemah dan aman untuk digunakan sebagai vaksin hidup yang dilemahkan. Penemuan ini juga bisa berfungsi sebagai peta jalan molekul untuk melakukan penelitian serupa pada corona virus lain, seperti MERS dan SARS, karena enzim ini umumnya terdapat pada semua keluarga korona virus.

\section{Pencegahan}

Pencegahan MERS dilakukan dengan perilaku hidup bersih dan sehat, menghindari kontak erat dengan penderita, menggunakan masker, menjaga kebersihan tangan dengan sering mencuci tangan memakai sabun dan menerapkan etika batuk ketika sakit. ${ }^{8}$ Langkah pencegahan infeksi MERS-CoV sama dengan pencegahan infeksi pada penyakit flu burung dan Emerging infectious Disease lainnya yang mengenai saluran napas. Hal yang harus dilakukan dalam pengendalian infeksi MERS-CoV: ${ }^{28}$

- Tindakan pencegahan transmisi droplet.

- Tindakan pencegahan standar diterapkan pada setiap pasien yang diketahui atau dicurigai memiliki infeksi pernapasan akut, termasuk pasien dengan dicurigai, probable atau terkonfirmasi MERS-CoV.

- Pencegahan infeksi dan tindakan pengendalian harus dimulai ketika pasien masuk triase dengan gejala infeksi pernapasan akut yang disertai demam.

- Pengaturan ruangan dan pemisahan tempat tidur minimal 1 meter antara setiap pasien ISPA dan pasien lainnya yang tidak menggunakan alat pelindung diri (APD).

- Pastikan triase dan ruang tunggu berventilasi cukup.

- Terapkan etika batuk.

- Tindakan pencegahan airborne digunakan untuk prosedur yang menimbulkan penularan aerosol. Risiko penularan pada petugas kesehatan meningkat ketika dilakukan tindakan intubasi trakea. Peningkatan risiko penularan SARS juga dilaporkan saat melakukan ventilasi non invasif, trakeostomi dan bantuan ventilasi dengan ambubag sebelum intubasi.

Secara hirarkis pencegahan dan penularan infeksi menurut infection prevention and control (IPC), yaitu pengendalian administratif, pengendalian dan rekayasa lingkungan, dan penggunaan alat pelindung diri (APD). ${ }^{30}$

Kewaspadaan pencegahan dan pengendalian infeksi meliputi:

1. Kewaspadaan standar (standard 
precaution) yang diterapkan di semua fasilitas pelayanan kesehatan dalam memberikan pelayanan kesehatan yang aman bagi semua pasien dan mengurangi risiko infeksi lebih lanjut.

2. Kewaspadaan pencegahan dan pengendalian infeksi tambahan ketika merawat pasien ISPA yaitu semua individu termasuk pengunjung dan petugas kesehatan yang melakukan kontak dengan pasien ISPA.

3. Kewaspadaan pencegahan dan pengendalian infeksi pada prosedur/tindakan medik yang menimbulkan aerosol $(<5$ mikron).

4. Kewaspadaan pencegahan dan pengendalian infeksi ketika merawat pasien probable atau konfirmasi terinfeksi MERS-CoV dengan membatasi jumlah petugas kesehatan, anggota keluarga dan pengunjung yang melakukan kontak dengan pasien suspek, probable atau konfirmasi terinfeksi MERS-CoV serta menunjuk tim petugas kesehatan terampil khusus yang akan memberi perawatan secara eksklusif kepada pasien.

5. Durasi tindakan isolasi untuk pasien harus diberlakukan selama gejala penyakit masih ada dan dilanjutkan selama 24 jam setelah gejala hilang.

6. Pengumpulan dan penanganan spesimen laboratorium. ${ }^{28}$

\section{Prognosis}

Banyak orang dengan konfirmasi MERS telah berkembang menjadi penyakit pernapasan akut parah, dan beberapa pasien mengalami disfungsi multi organ. Kasus kematian telah dilaporkan mencapai $30 \%$, meskipun jumlah ini kemungkinan lebih tinggi menyusul laporan baru-baru ini bahwa Arab Saudi tidak melaporkan jumlah keparahan kasus di negara itu. Revisi angka kematian diArab Saudi sekarang melebihi 40\% (dari 688 kasus yang dilaporkan dengan 282 kematian). Angka kematian yang tinggi mungkin dikarenakan penetapan diagnosis yang tertunda, kurangnya terapi yang efektif, adanya komorbiditas, termasuk stadium akhir penyakit ginjal yang menjalani hemodialisis, diabetes, maupun penyakit kronis jantung paru, di mana semuanya diketahui dapat meningkatkan angka kematian. ${ }^{3}$

\section{Simpulan}

Middle East Repiratory Syndrome (MERS) merupakan penyakit pernapasan yang disebabkan oleh MERS-CoV. Transmisi terjadi melalui kontak dekat dengan orang yang terinfeksi, termasuk dari pasien ke petugas kesehatan.

Menurut WHO, klasifikasi kasus MERS-CoV yaitu penyelidikan, probable dan konfirmasi. Tampilan klinis MERS berkisar dari asimtomatik sampai sindrom distres pernapasan akut dan kegagalan multi organ yang menyebabkan kematian, khususnya pada individu dengan komorbiditas sebelumnya. Pemeriksaan laboratorium untuk MERS-CoV sendiri tidak tersedia secara rutin, namun PCR untuk MERS-CoV tersedia di beberapa laboratorium pelaksana dan balai penelitian dan pengembangan kesehatan (Balitbangkes) di Jakarta.

Hingga saat ini belum ada vaksin yang tersedia untuk MERS dan belum ada pengobatan khusus yang telah direkomendasikan. Terapi infeksi MERS bersifat suportif tergantung kondisi keadaan pasien, berupa pemberian hidrasi, antipiretik, analgesik, bantuan pernapasan, dan antibiotik jika diperlukan untuk mengatasi infeksi sekunder.

\section{DAFTAR PUSTAKA}

\section{Rha B, Rudd J, Feikin D, Watson J, Curns AT, Swerdlow DL, dkk. Update on the epidemiology of Middle East Respiratory Syndrome Corona- virus (MERS-CoV) infection, and guidance for the public, clinicians, and public health authorities. MMWR 2015; 64(3):61-2.}

2. McNeil DG. Saudi Arabia: MERS toll revised. The New York Times. June 4, 2014. [cited 2015 June 22]. Available 
from: http://www. nytimes.com/2014/ 06/04/health/saudi-arabia-mers-toll revised.html?emc=eta1\&_r $=0$.

3. Alimuddin Z, Hui DS, Perlman S. Middle East respiratory syndrome. London. 2015:1-9.

4. Center of Diseases Control. Middle East Respiratory Syndrome (MERS). Frequently asked questions and answers. [cited 2015 June 22]. Available from: http://www.cdc.gov/ coronavirus/mers/faq.html.

5. Center of Diseases Control. Announces first case of Middle East Respiratory Syndrome Corona-virus infection (MERS) in the United States. [cited 2015 June 22]. Available from: http://www.cdc.gov/media/releas es/2014/p0502-US-MERS.html.

6. Falzarano D, de Wit E, Rasmussen AL, Feldmann F, Okumura A, Scott DP, et al. Treatment with interferon- $a 2 b$ and ribavirin improves outcome in MERS$\mathrm{CoV}$ infected rhesus Macaques. Nat Med .2013;19(10):1313-7.

7. Center of Diseases Control. Middle East Respiratory Syndrome (MERS). [cited 2015 June 22]. Available from: http://www.cdc.gov/coronavirus/ mers/interim-guidance.html.

8. Slamet, Bratasena A, Sitorus M, Rizkiyati N, Samoedro E, Wignjadiputro I, et al. Pedoman umum kesiapsiagaan menghadapi Middle East Respiratory Syndrome Corona-virus (MERS-CoV). Kementrian Kesehatan Republik Indonesia, Direktorat Jendral Pengendalian Penyakit dan Penyehatan Lingkungan, 2013; p. 1-12.

9. Woo PC, Lau SK, Huang Y, Yuen KY. Corona-virus diversity, phylogeny and interspecies jumping. Exp Biol Med. 2009;234(10):1117-27.

10. Mole B. Deadly corona-virus found in bats. Nature.com. [cited 2015 June 22]. Available from: http://www.nature.com/news/deadlycoronavirus-found-in-bats-1.13597.

11. Hemida MG, Chu DKW, Poon LM. MERS Corona-virus in Dromedary Camel Herd, Saudi Arabia. CDC. [cited 2015 June 22]. Available from: http://wwwnc.cdc.gov/eid/article/ 20/7/14-0571_article.htm.

12. Roos R. MERS outbreaks grow; Malaysian case had camel link. University of Minnesota. [cited 2015 June 22].

Available from: http://www. cidrap.umn.edu/news-perspective/2014/ 04/mers-outbreaks-grow-malaysiancase-had-camel-link

13. Reusken CB, Haagmans BL, Muller MA, Gutierrez C, Godece GJ, Meyer B et al. Middle East Respiratory Syndrome Corona-virus neutralising serum antibodies in Dromedary Camels: a comparative serological study. Lancet Infect Dis. 2013;13(10):859-66.

14. Kupferschmidt K. Camels may transmit new Middle Eastern Virus. Science. [cited 2015 June 22]. Available from: http://news.sciencemag.org/health/2013 /08/camels-may-transmit-new-middleeastern virus.

15. Hemida MG, Perera RA, Wang $P$, Alhammadi MA, Siu LY, Li M, et al. Middle East Respiratory Syndrome (MERS) Corona-virus seroprevalence in domestic livestock in Saudi Arabia, 2010 to 2013. Euro Surveill. 2013; 18(50):206-59.

16. World Health Organization. Middle East Respiratory Syndrome Corona-virus (MERS-CoV) summary and literature update. [cited 2015 June 22]. Available from: http://www.who.int/csr/disease/ coronavirus_infections/MERS_CoV_U pdate_09_May_2014.pdf?ua=1.

17. Haagmans BL, Al Dhahiry SH, Reusken CB, Raj VS, Galiano M, Myers R, et al. Middle East Respiratory Syndrome Corona-virus in Dromedary Camels: an outbreak investigation. Lancet Infect Dis. 2014;14(2):140-5.

18. World Health Organization. Middle East Respiratory Syndrome coronavirus (MERS-CoV) in Thailand. [cited 2015 June 22]. Available from: http://www. who.int/csr/don/20-june-2015-mersthailand/en/.

19. World Health Organization. Frequently asked questions on Middle East Respiratory Syndrome Corona-virus (MERS-CoV). [cited 2015 June 22]. Available from: http://www.who.int/ csr/disease/ corona virus_infections/faq/en/

20. World Health Organization. Corona-virus infections. [cited 2015 June 22]. Available from: http://www.who.int/ csr/disease/coronavirus_infections/en/. 
21. World Health Organization. Middle East Respiratory Syndrome Corona-virus (MERS-CoV). [cited 2015 June 22]. Available from: http://www.who.int/ emergencies/mers-cov/en/.

22. Assiri A, McGeer A, Perl TM, Price CS, Al Rabeeah AA, Cummings DA, et al. Hospital outbreak of Middle East Respiratory Syndrome Corona-virus. N Engl J Med. 2013;369(5):407-16.

23. Guery B, Poissy J, el Mansouf L, Sejourne C, Ettahar N, Lemaire X, dkk. Clinical features and viral diagnosis of two cases of infection with Middle East Respiratory Syndrome Corona-virus: a report of nosocomial transmission. Lancet. 2013;381(9885): 2265-72.

24. Slamet, Bratasena A, Rizkiyati N, Sitorus M, Samoedro E, Nadhirin, dkk. Pedoman surveilans dan respon kesiapsiagaan menghadapi Middle East Respiratory Syndrome Corona-virus (MERS-CoV). Kementrian Kesehatan Republik Indonesia, Direktorat Jendral Pengendalian Penyakit dan Penyehatan Lingkungan, 2013; p. 1-34.

25. Setiawati V, Pawestri HA, Susilarini NK, Andriana KN, Roselinda, Sudomo M dkk. Pedoman pengambilan spesimen dan pemeriksaan laboratorium Middle East Respiratory Syndrome Coronavirus (MERS-CoV). Kementrian Kesehatan Republik Indonesia, Direktorat Jendral Pengendalian Penyakit dan Penyehatan Lingkungan, 2013; p. 1-6.
26. World Health Organization. Corona-virus infections. [cited 2015 June 22]. Available from: http://www.who.int/ csr/disease/coronavirus_infections/en/.

27. Reusken C, Mou H, Godeke GJ, van der Hoek L, Meyer B, Muller MA, et al. Specific serology for emerging human Corona-viruses by protein microarray. Euro Surveill. 2013; 18(14):204-41.

28. Slamet, Bratasena A, Sitorus M, Rizkiyati N, Samoedro E, Wignjadiputro I, et al. Pedoman tatalaksana klinis infeksi saluran pernapasan akut berat suspek Middle East Respiratory Syndrome Coronavirus (MERS-CoV). Kementrian Kesehatan Republik Indonesia, Direktorat Jendral Pengendalian Penyakit dan Penyehatan Lingkungan, 2013; p. 1-15.

29. Al-Tawfiq JA, Momattin H, Dib J, Memish ZA. Ribavirin and interferon therapy in patients infected with the Middle East Respiratory Syndrome Corona-virus: an observational study. Int J Infect Dis. 2014;20:42-6.

30. Slamet, Burhan E, Agustina P, Samoedro E, Handayani D, Agustin $\mathbf{H}$, et al. Pedoman pencegahan dan pengendalian infeksi kasus konfirmasi atau probable infeksi virus Middle East Respiratory Syndrome Corona-virus (MERS-CoV). Kementrian Kesehatan Republik Indonesia, Direktorat Jendral Pengendalian Penyakit dan Penyehatan Lingkungan, 2013; p. 1-16. 